Article

\title{
Transcendental Trinitarian: James Marsh, the Free Will Problem, and the American Intellectual Context of Coleridge's Aids to Reflection
}

\author{
Jonathan Koefoed \\ Department of History, Belhaven University, 1500 Peachtree St., Jackson, MS 39202, USA; \\ jkoefoed@belhaven.edu
}

Received: 19 July 2017; Accepted: 8 August 2017; Published: 30 August 2017

\begin{abstract}
Historians of American religion and Transcendentalism have long known of James Marsh as a catalyst for the Concord Transcendentalist movement. The standard narrative suggests that the Congregationalist Marsh naively imported Samuel Taylor Coleridge's Aids to Reflection (Am. ed. 1829) hoping to revivify orthodoxy in America. By providing a "Preliminary Essay" to explain Coleridge's abstruse theology, Marsh injected Coleridge's hijacked Kantian epistemology-with its distinction between Reason and Understanding-into American discourse. This epistemology inspired Transcendentalists such as Ralph Waldo Emerson and Bronson Alcott, and it helped spark the Transcendentalists' largely post-Christian religious convictions. This article provides a re-evaluation of Marsh's philosophical theology by attending to the precise historical moment that Marsh chose to publish the Aids to Reflection and his "Preliminary Essay." By the late 1820s, the philosophical problem of free will lurked in American religious discourse-Unitarian as well as Trinitarian—and Marsh sought to exploit the problem as a way to explain how aspects of Trinitarian Christianity might be rational and yet unexplainable. Attending carefully to the numerous philosophical and religious discourses of the moment-including Unitarianism, Trinitarianism, Kant, Coleridge, and Scottish Common Sense-and providing close readings of the historical philosophers Marsh engaged, this article shows how James Marsh laid the epistemological groundwork for a new romanticized Christianity that was distinct from the Concord Transcendentalists, but nonetheless part of its historical lineage.
\end{abstract}

Keywords: James Marsh; Transcendental; Romantic; Christianity; American religion; free will; Coleridge; Trinitarian; Unitarian; Scottish Common Sense; Kant

\section{Introduction}

In 1834, prior to composing his many notable works, Ralph Waldo Emerson wrote to his brother. "Do you draw the distinction of Milton, Coleridge \& the Germans between Reason \& Understanding. I think it a philosophy itself \& like all truth very practical" (Emerson 1939, p. 412). ${ }^{1}$ For Emerson, Reason was the faculty of intuitive perception, spiritual vision, religious experience, poetic creativity, aesthetic wonder, and heroic action (Emerson 1939, p. 413). The Understanding was the mind's discursive and dissecting faculty -it "compares, contrives, adds, [and] argues"; it questioned Reason's insights; and it functioned as a "wrinkled calculator ... committed to the support of our animal life" (Emerson 1939, p. 413). Reason was a unique birthright of all human beings, akin to the Quakers' inner light, and it served according to Robert Richardson as "the fundamental basis" of Emerson's doctrine of self-reliance and his celebration of democracy (Richardson 1995, pp. 166-67, 185). The epistemological distinction

1 Ralph Waldo Emerson to Edward Bliss Emerson, 31 May 1834. 
went beyond Emerson. According to Lawrence Buell this notion of a higher reason-sometimes going by different names-lay at "the heart" of the Transcendentalist movement (Buell 1973, p. 5). ${ }^{2}$

As scholars of Transcendentalism have long recognized, the reason-versus-understanding distinction had a specific lineage. ${ }^{3}$ It was Kantian language, co-opted by Samuel Taylor Coleridge and filtered in a precise historical way by the University of Vermont philosophy professor and president, James Marsh. In a "Preliminary Essay," Marsh pressed Coleridge's reason-versus-understanding distinction hoping to reconstitute Trinitarian Christianity in America. Whatever Marsh's objective philosophical merits, the work proved influential beyond the Concord Transcendentalists. Coleridge's Aids to Reflection had been available for several years, but between November of 1829 and February of 1830 Marsh's edition sold all 1500 copies of its initial printing with the publisher soon asking for a second edition to meet demand (Duffy 1973, p. 108). ${ }^{4}$ Even as late as 1842, Emerson reported that demand for Aids to Reflection remained brisk at Andover seminary, one of the most influential orthodox seminaries in the country (Nicolson 1925, p. 41).

Intellectual and religious history remembers Marsh primarily for publishing Coleridge and for inadvertently sparking the more religiously radical Concord Transcendentalists. ${ }^{5}$ Such a generalized understanding has caused the American intellectual historian James Turner to declare that Marsh is "an unjustly neglected figure in American intellectual history" (Turner 1985, p. 106). In the last thirty years since Turner no monographs or substantial syntheses of Marsh's thought have appeared. Samantha Harvey has shown how Marsh's educational thought and reforms had a long-term influence on American Pragmatism; Walter Conser has provided brief elaborations of Marsh's connection to Germany, Marsh's theories of language, and Marsh's social theory; and John Beer has helpfully summarized much previous scholarship while highlighting the ongoing significance of Marsh's edition of Coleridge's Aids on both sides of the Atlantic (Harvey 2011, pp. 77-103; Conser 1986, pp. 259-66; Conser 1993, pp. 84-89, 123-29; Beer 1993, pp. cxvi-cxxviii).

Turner's call for more work on Marsh was remarkable, for the vast majority of scholarship on Marsh had already been published. Majorie Nicolson had set the stage for Marsh scholarship by outlining his basic philosophical position; naming but not exploring his philosophical influences; and framing him as the "founder" of the Transcendentalist movement and the sustainer of a "Vermont School of Transcendentalism" (Nicolson 1925, pp. 29-30, 34). Building on Nicolson, scholars tried to identify what it was that defined Marsh's alternative transcendentalism: some argued that it was an evangelical Protestant liberalism; Peter Carafiol argued that it was Marsh's commitment to conservative Puritan orthodoxy; Louis Feuer argued that it was Marsh's political conservatism; and John J. Duffy suggested that it was a cultural conservatism that mourned the dissociated sensibility of the modern age, à la T.S. Eliot (Huntington 1892, pp. 28-30, 41; Buckham 1904, p. 316; Wells 1943, pp. 146-47; McGiffert 1969, pp. 437, 443-35, 452, 457; Carafiol 1975, pp. 128-30; Carafiol 1982, pp. xv, 5, 18-22, 49-50, 55, 59; Feuer 1958; Duffy 1970a, pp. 38-39). ${ }^{6}$ A few scholars have attended to Marsh's educational vision and his influential reforms at the University of Vermont (Lindsay 1936; Lindsay 1954, pp. 129-68; White 1965; Swift 1972). And despite Turner's lament, there have been several sustained philosophical treatments of Marsh (Wells 1943, pp. 14-48; Harding 1979; Carafiol 1982, pp. 34-84; Kuklick 1985, pp. 146-151). While all of these philosophical treatments have read Marsh closely and alongside Coleridge, only John Dewey and Henry Pochmann have provided sustained

2 I have refrained from capitalizing 'Reason' and 'Understanding' in this essay, for while Emerson did so, James Marsh generally did not, and Coleridge was inconsistent.

3 While a clearly definable set of criteria for Transcendentalism is elusive, I have followed the general convention to capitalize the term. On the question of definition see (Myerson 2000, pp. xxv-xxxvii).

4 James Marsh (JM) to Samuel Taylor Coleridge (STC), 24 February 1830.

5 For a few among many examples in the literature on Transcendentalism see (Miller 1978, pp. 34-35; Greenwood 1984, pp. 343-44; Harvey 2013, pp. 26-34). A more developed account of Marsh's thought, but still framed fully as a precursor to Transcendentalism is (Gura 2007, pp. 47-53). For examples in American intellectual and religious history see (Perry 1984, pp. 219-20; Holifield 2003, pp. 436-37).

6 See the first four sources on Marsh's theological liberalism. 
readings of Marsh's philosophy alongside the original writings of other historical philosophers so important to his context and project-in this case Kant and Aristotle (Dewey 1941; Pochmann 1957, pp. 131-43). ${ }^{7}$ This article seeks to extend and build on the previous philosophical studies of Marsh by providing a fresh reading alongside Kant and Coleridge and by looking more closely at many of the historical philosophers-Thomas Reid, Thomas Brown, Dugald Stewart, and Nathanial William Taylor-that were so central to Marsh's project in its intellectual milieu.

This essay argues that the key to Marsh's influence and attraction in 1829 lay in his "Preliminary Essay" as a work of contextual philosophical theology. Attending to this work in historical-philosophical context reveals several parts of Marsh's philosophical theology not yet fully understood. First, the interpretive key to the "Preliminary Essay" was Marsh's quintessentially Romantic obsession with the liberation of the self-which for Marsh took the form of the philosophical free will problem appreciated only by a reflective inward gaze on one's own mind (Fairchild 1974, pp. 208-9, 211, 217-18; Frye 1974, pp. 304-5, 308; Cranston 1994, pp. 13-14; Berlin 1999, pp. 8-10, 94-95; Breckman 2008, pp. 3, 6; Richardson 1995, pp. 184-85; Howe 1997, pp. 2-3, 189-91; Capper 2007, pp. xi-xii; Gura 2007, p. xv). ${ }^{8}$ While several scholars have noticed Marsh's fear of determinism, this essay makes that fear central to interpreting Marsh's "Preliminary Essay" (Wells 1943, pp. 38-43; Duffy 1973, pp. 15, 28; Harding 1979, pp. 241-42; Beer 1993, p. cxviii). ${ }^{9}$ Second, at the precise moment that Marsh chose to publish his "Preliminary Essay," the free will problem had become critically important in the American intellectual tradition-particularly the Scottish Common Sense philosophy that grounded American thought. Third, Marsh's attention to the free will problem made his project much closer to Immanuel Kant's moral philosophy than is often recognized, suggesting that Marsh likely knew Kant and was a more synthetic thinker than is sometimes acknowledged. Fourth, Marsh's use of the free will problem meant that he broke significantly with the Edwardsian and Calvinist traditions that dominated orthodoxy despite remaining a broadly orthodox Trinitarian. And finally, Marsh's appeal was so widespread not only because of his attack on Scottish Common Sense, as we have long known, but also because he carefully chose his targets and rejected a point-by-point polemic against its two most important thinkers: Thomas Reid and Dugald Stewart. In fact, as we shall see, there were features of Reid and Stewart that worked in favor of Marsh's polemic against his primary intellectual targets: John Locke, Thomas Brown, Jonathan Edwards and the American Edwardsian tradition, and the American Unitarians. In sum, by taking the frequent observation by scholars that Marsh feared determinism and understanding it as the interpretive key to Marsh's entire philosophy and for understanding Marsh as a Romantic thinker, we gain a much better appreciation for Marsh's philosophical theology and his purposes in promulgating it. We also gain a deeper historical understanding of the reason-versus-understanding distinction, its significance in its historical moment, and why the distinction proved so important to Transcendentalism.

\section{Scottish Common Sense}

Scottish Common Sense philosophy_including its metaphysics, epistemology, and moral philosophy-dominated American philosophy from the American Revolution until Marsh's time and beyond. In its most basic form, Scottish Common Sense postulated numerous intuitive principles in the mind by which humans ordered their experience. These were common sense principles that no rational person questioned. For Americans one of the primary attractions to Scottish Common Sense philosophy was its moral clarity and political suitability, especially as Scottish thought initially

7 For a brief exploration of Cambridge Platonism in its original sources see (Carafiol 1982, pp. 44-47).

8 Elaborating the literature that supports this sentence would require a historiography of Romanticism. The first five authors speak to the centrality of the self for European Romanticism; the latter four speak of the centrality of the self to American Romanticism.

9 Peter Carafiol identifies Marsh's concern with free will, but relative to Marsh's later writings, not the "Preliminary Essay," and Carafiol links Marsh very closely to Jonathan Edwards on the question (Carafiol 1982, pp. 68-69). This essay distinguishes Marsh from Edwards on the question. 
gained traction in the late-eighteenth century. A ubiquitous common sense simultaneously justified established communal moral and religious truths but did so in a rapidly changing political climate that emphasized the trustworthiness of the common man in political and moral matters. In the hope of creating a stable republic with the volatile, egalitarian logic of the Declaration of Independence and spreading popular political power, Common Sense philosophy relished well (Noll 2002, p. 113; Meyer 1972, p. 42). ${ }^{10}$

But although moral philosophy and political suitability were the strongest motivations for the wide adoption of Scottish Common Sense, by the time Marsh published his "Preliminary Essay" Thomas Reid and Dugald Stewart-by far the two most comprehensive Common Sense philosophers-had gained a more comprehensive purchase on the American mind. Two separate publishers from 1813-1815 and in 1822 issued Reid's complete works in American editions, suggesting strong demand. ${ }^{11}$ In the 1820's Stewart became standard—though not ubiquitous-reading in college courses on the philosophy of mind, and an American edition of his complete works debuted in 1829, simultaneous to Marsh's "Preliminary Essay" (Snow 1907, pp. 122, 126, 129). ${ }^{12}$

Like Immanuel Kant in Germany, Scottish Common Sense philosophy was provoked by another Scot, David Hume. Hume undermined the empirical realism at the heart of British philosophy by arguing that if all knowledge ultimately derived from discreet, individual sense perceptions-as John Locke had essentially maintained - then much supposed human knowledge about the external world and its governing laws could not be justified. In particular, Hume argued that the law of causation, which grounded empirical science, could not be rationally explained. I may feel wind blow and I may see leaves fall from trees, but if each of these perceptions are truly discreet sense perceptions, all I can be sure of is a frequent coincidence between the two events. The father of Scottish Common Sense, Thomas Reid, responded that the mind possessed "first principles," elsewhere called principles of common sense, which arose "from the constitution of our nature" (Reid 1813, p. 250). These were neither a product of reason nor of sensation, they were simply intuitive principles within the mind that structured the mind's encounter with the world and with itself. Personal identity, causation, free will, space, time, the moral laws of conscience, mathematical axioms, the reliability of our physical sensations, our mental perceptions, and our memories were all principles that no rational person could function without. Therefore, they must be reliable, intuitive principles (Reid 1813, pp. 195, 199, 234-35, 250, 255, 283, 415-22; Reid 1814, pp. 33-38, 294, 328, 331, 338, 353; Reid 1815a, pp. 99-109, 135, 153, 159-74, 189-208, 398; Reid 1815b, pp. 215-18, 252-56). Reid also maintained that the existence of the external world and God's existence enjoyed this status as a first principle (Reid 1813, p. 255; Reid 1815a, pp. 153, 158). In America, Reid's system provided an adequate response to Hume and preserved numerous principles foundational not only to morality and politics, but also to American theology. Scottish Common Sense was an epistemological framework all parties could agree on while they argued primarily about the interpretation of the Bible and the role of reason in interpreting revelation.

\section{Toward a New Epistemology: Marsh, Kant, and Common Sense}

The key to understanding Marsh's "Preliminary Essay" is to recognize that while Marsh attacked the dominant epistemology, he never articulated a point-by-point critique of either Thomas Reid or Dugald Stewart, the two most comprehensive thinkers in the Scottish School. Instead, Marsh lumped John Locke, Thomas Brown, and the other Scottish writers together as members of a single British empiricism that had "been received in full faith, as the only rational system" and

10 On the Common Sense tradition in the American South see (O'Brien 2004, pp. 1008-1012); for an insightful discussion of the subtle use of Common Sense for political purposes in Thomas Paine's work and moment see (Rosenfeld 2011, pp. 136-180, especially pp. 138-39, pp. 145-47).

11 The publishers were Samuel Etheridge Jr. of Charlestown in 1813-1815 and E. Duyckinck, Collins, and Hannay, and R. and W.A. Bartow of New York in 1822.

12 In 1820 the University of Pennsylvania still utilized "Locke's Essays" for the "Science of the Mind" (Snow 1907, p. 139). The publisher of Stewart's complete works was Hilliard and Brown of Cambridge, MA. 
as inextricably intertwined with all American theology (Marsh 1829, p. xlv). Marsh's objection had several components. First, although Reid's and Stewart's epistemology was now fully available, Marsh thought that most American writers used an appeal to "common sense" as a dodge around complicated philosophical questions (Marsh 1829, p. xxii). Second, Scottish Common Sense failed to provide any rational defense for the traditional Christian doctrines of Trinity and Incarnation. Reid and Stewart understandably never touched the issue; they were philosophers attempting to combat Humean skepticism, not theologians interested in defending controversial doctrines. But the problem went deeper: the methodological appeal to common sense on esoteric questions such as free will or the existence of the external world worked against any attempt to explain the paradoxical Christian doctrines as rational. According to Marsh, the prevailing philosophical system was "at war with orthodox views of religion," and he claimed many orthodox theology professors had admitted as much privately (Marsh 1829, p. xlv). Finally, Scottish Common Sense vitiated "everything distinctly spiritual" in Christianity (Marsh 1829, p. xlvii). It gave no account of or inducement to spiritual experience-as would Coleridge's and Emerson's epistemology—and its overly rationalistic emphasis on Baconian induction in mental philosophy created an unsympathetic atmosphere to spiritual insight, whether of the religious or aesthetic variety.

On the question of reason, Marsh introduced his and Coleridge's most enduring distinction: the quasi-Kantian distinction between reason and understanding-which so fired the Transcendentalists. But why was this distinction necessary? For Kant the distinction served, among other things, to give an account of the relationship between causation and human free will. Kant's distinction between phenomenal perception of the world—organized as it was by the categories of the understanding-and his postulating a noumenal world of things in themselves to which humans did not have direct access, allowed him to eventually give an intriguing response to the most bedeviling problem in philosophy, namely the free will problem. If causation was a category of the understanding, and may or may not exist in the way we conceive of it in the noumenal world, then free will might in fact be at play despite the understanding's inability to properly perceive or articulate free will since the understanding always insisted on organizing all experience and perception as cause-and-effect (Adams 1998, pp. ix-x). On the other hand, for Kant the practical (moral) reason established free will as unquestionable, for without it such moral notions as praise, blame, guilt, desert, and justice itself held little meaning.

This was not very different from Scottish Common Sense, which maintained that causation and free will were both common sense, intuitive principles in the mind. On the precise status of these intuitive principles, however, the Scottish tradition was less than clear. Thomas Reid was more interested in laying out a substantial list of first principles than in carefully explaining their relationship to one another. For Reid, causation was a "metaphysical first principle" while free will was a "contingent first principle"; there were "physical laws of nature" and "moral laws of nature" (Reid 1815a, pp. 170-72, 191, 194-208; Reid 1815b, p. 284). The latter applied to rational agents only. But elsewhere, Reid seemed to suggest that the idea of causation arose from a more fundamental sense of our own free will as causative agents; thus it was not clear whether the metaphysical principle of causation was actually derived from the more fundamental contingent first principle of free will (Reid 1815b, pp. 386-90). He also maintained that the belief that no one should be blamed for an action if they had not the power to prevent it was a "moral first principle," but he did not explain whether this moral first principle could also be derived from the contingent first principle of free will (Reid 1815a, p. 191). In the end, the Scottish tradition tended to, in D.H. Meyer's words, "confuse matters of fact with matters of logic, of value, and of faith; and there was always the temptation to overextend oneself in claims to certainty" (Meyer 1972, pp. 39-40). It was this confusion that Marsh sought to exploit in order to introduce a new quasi-Kantian way of talking about the mind.

Reid's first principles were an effective response to Hume, especially for American intellectuals largely unconcerned with epistemological technicalities, but Kant thought otherwise. Reid's frequent positing of different kinds of first principles led Kant to accuse proponents of Scottish Common Sense of being unable to justify their list of first principles or explain their relationship in the human 
constitution (Malherbe 2003, pp. 310-11). The Scots, particularly Dugald Stewart and Thomas Brown, responded by labeling Kant an unoriginal jargon monger, although behind the scenes Stewart seemed to take Kant's criticisms of Reid seriously (Mortera 2012, pp. 125-26, 135; Friday 2005, pp. 275-85). According to Marsh, Stewart had swept the field in America as Stewart's History of Philosophy effectively scared off Americans from reading Kant and the German idealists (Duffy 1973, pp. 80-81). ${ }^{13}$ Although in the end the Scots had a great deal in common with Kant, a strong language barrier-Kant did not read English and Stewart did not read German-and national chauvinism conspired to forestall much productive engagement until the later Scots James Mackintosh and William Hamilton began to rectify the situation (Malherbe 2003, pp. 299-301; Mortera 2012, pp. 126, 135). ${ }^{14}$ What made Marsh so significant in American intellectual discourse in 1829 was that his "Preliminary Essay" - with its reason-versus-understanding distinction and its obsession with the free will problem-stood at the center of a much larger Anglo-Germanic philosophical debate.

\section{The Fraying of the Edwardsian Tradition: American Philosophical Theology in the 1820s}

The key to understanding what Marsh thought he was doing lay also in the American historical context. Between 1827 and 1829, four important texts emerged that suggested that the union between American theology and Scottish Common Sense had run into trouble, at least on the free will problem. These texts were Thomas Upham's Elements of Intellectual Philosophy (Upham 1827), Levi Hedge's condensed edition of Thomas Brown's A Treatise on the Philosophy of the Human Mind (Brown 1827), Nathaniel William Taylor's Concio ad Clerum (Taylor 1842), and Dugald Stewart's Philosophy on the Active and Moral Powers of Man (Stewart 1829). ${ }^{15}$ The importance of these texts will become clear in the following discussion.

For some time the orthodox Congregationalists and Presbyterians had become vulnerable to charges by Unitarians that Calvinist doctrines of depravity and arbitrary election undermined what the Unitarian spokesman William Ellery Channing called "the moral perfection of God" (Channing 1843, p. 82). A God who knew full well that humanity would be corrupted by Adam's sin, chose to create, and then still held people accountable to a standard they had no way of fulfilling could not be just. On the Calvinist system, God provided salvation to be sure, but only for an elect, seemingly arbitrary number. For emphasis, Channing pressed home the effects of this system: "It tends to discourage the timid, to give excuses to the bad, to feed the vanity of the fanatical, and to offer shelter to the bad feelings of the malignant ... shocking as it does the fundamental principles of morality, and ... exhibiting a severe and partial Deity" (Channing 1843, p. 87). In other words, Channing thought that the orthodox position was clearly contrary to reason.

The orthodox felt the sting, and just prior to Marsh's "Preliminary Essay," the Yale professor Nathaniel William Taylor began to articulate an alternative orthodox position that culminated in his Concio ad Clerum (Taylor 1842). Taylor insisted that human beings had thorough free will, and that human nature was not inherently depraved, even by the effects of Adam's fall. Humans had a "disposition or tendency" to sin that was not in itself sinful, but this disposition in their nature meant "that in all the appropriate circumstances of their being, they will sin and only sin" (Taylor 1842, pp. 8, 15). Because of Adam's fall, all humans would inevitably sin at the earliest possible chance when coming into a sinful world, but they were not compelled to do so.

While Marsh agreed in principle with Taylor's cautious liberation of the will, there were several features of Taylor's position which would pose problems for Marsh's Coleridgean approach. First, Taylor grounded his philosophy fully on Scottish Common Sense, and methodological appeals to common sense could only undermine the reasonability of Christian doctrines like the Trinity. ${ }^{16}$ Taylor

\footnotetext{
JM to STC, 21 March 1829.

4 For a helpful comparison which sees both Kant and Common Sense as very similar see (Ameriks 2005, especially pp. 23-30).

15 Stewart's work appeared in both Edinburgh and Boston editions in 1828.

6 On Taylor and Common Sense, see (Holifield 2003, p. 355).
} 
himself seemed to sense that Trinitarians were faring poorly in these debates with Unitarians (Holifield 2003, pp. 347, 355). Second, Taylor was too committed to the Edwardsian tradition, citing Edwards more than any other theologian in defense of his doctrine of salvation throughout his writings (Sweeney 2003, p. 117). ${ }^{17}$ In the Preface to his Concio ad Clerum, Taylor claimed that his views did not differ from his Yale mentor Timothy Dwight-“"his revered instructor in theology" (Taylor 1842, p. 3). Dwight had always remained faithful to Edwards, believing that free will did not require actual self-determination or the ability to choose between competing desires (Holifield 2003, p. 352).

Marsh had little interest in fidelity to Edwards or the Edwardsian tradition, and his "Preliminary Essay" sought to undermine much of the Edwardsian scheme as well as the Scottish Common Sense philosophy allied to it. Marsh lauded developments in theology like Taylor's, but for opposite reasons. Taylor sought to rescue and update the Edwardsian tradition; Marsh thought Taylor's ideas likely "to shake the authority of Edwards among [the orthodox]" (Duffy 1973, p. 80).$^{18}$ Indeed, by publishing and promoting Aids to Reflection, Marsh was stoking the fire. In Aids Coleridge mercilessly attacked Jonathan Edwards as a determinist, labeling him worse than even Luther and Calvin because of Edwards' cool, single-minded commitment to such an odious idea. Coleridge blamed Jonathan Edwards for solidifying a logically magisterial but hopelessly stringent Calvinist determinism-a backhanded tip of the hat to the backwoods philosopher's great but misdirected intellect. As if to mock any rehabilitation of Edwards, Coleridge declared that compared to Luther's or Calvin's "captive and enslaved Will" Edwards proffered "no Will at all" (Coleridge 1829, pp. 105-7). ${ }^{19}$

When Marsh published his "Preliminary Essay," there were serious problems as well in fusing Scottish Common Sense and the Edwardsian tradition. In 1828 Dugald Stewart finally provided a sustained discussion of free will in an appendix to his Philosophy on the Active and Moral Powers of Man (Stewart 1829), after putting off the project for most of his career. In the appendix, Stewart dismissed Edwards as the most able necessitarian philosopher in recent memory but guilty of "the most dangerous errors of Hobbes and his disciples" (Stewart 1829, p. 585). Stewart's clear assault upon Edwards, delivered in the same year as Taylor's Concio ad Clerum, showed the serious cracks between philosophy and theology in New England. It was Stewart upon whom Taylor drew most especially in his philosophy (Holifield 2003, p. 355). These fractures suggested that orthodoxy's attempt to ground its theology on Common Sense philosophy was at least unstable and perhaps impossible. Since Marsh was not dogmatically committed to all facets of traditional Puritan orthodoxy, he might have embraced Stewart's insistence on free will and moved on. But Marsh seems to have worried not only that Common Sense provided no account of or inducement to spiritual experience or a framework for assenting to the doctrines of the Trinity and Incarnation, he also worried that Common Sense as an intellectual tradition was itself wearing thin, evidenced by its recent and highly-lauded scion, Thomas Brown.

\section{Free Will and the Problem of Thomas Brown}

While Marsh criticized Calvinist orthodoxy, his primary target was the Unitarians as he sought to turn the discussion of free will back on them. His strategy was to embrace the Unitarian moral critique of Calvinist determinism so as to wield it against them and attempt to vindicate the other orthodox doctrines they attacked. To be sure, Marsh conceded, the Unitarians asserted that free will existed, but they could give no consistent account of it. The precipitating issue for Marsh was the surging popularity of Thomas Brown, a scion of Common Sense who harbored Humean skeptical

17 Holifield agrees that Taylor was trying merely to correct an overemphasis on human dependence in the Edwardsian tradition, but was still a Calvinist (Holifield 2003, p. 354).

18 JM to STC, 23 March 1829.

19 Marsh was aware of how offensive this would be to his audience, and he attempted to channel his readers' objections to other parts of the Aids to reinforce the need for Coleridge's overall epistemology, see Marsh's Note 45 in (Coleridge 1829, pp. 282-83). 
sympathies about religion, leaned heavily toward determinism on questions of causation, subtly attacked Dugald Stewart by attacking Thomas Reid, and according to both contemporary and later critics was a proto-Comtean positivist (Dixon 2003, pp. 109-16). ${ }^{20}$ What flummoxed Marsh was that despite these many problems, Unitarians seemed to blithely embrace Brown, suggesting serious problems with their philosophical-theological synthesis.

In 1827, two of the first American college textbooks on the philosophy of mind appeared, both of which praised Brown and utilized him extensively. The Unitarian Levi Hedge edited and released Brown's Philosophy of the Human Mind in two volumes to be used "as a textbook in seminaries of education" for which purpose, Hedge insisted, "it possesses on many accounts, pre-eminent claims" (Brown 1827, pp. 1:v-vi). Till that point, Hedge's Elements of Logick had provided what Daniel Howe has called "the definitive presentation of the Scottish theory of knowledge" for the Unitarians (Howe 1970, p. 33). Brown's appeal was not limited to the Unitarians, although in adopting him as the primary textbook on the philosophy of mind they seemed most favorable to him. Among the orthodox, Thomas Cogswell Upham-a professor at Bowdoin College-published Elements of Intellectual Philosophy (Upham 1827), which drew on Locke, Stewart and Brown. Of Brown, Upham declared: “Unhappily for the science [of intellectual philosophy] he was cut off from life before he was permitted to complete and give to the world in his own name his analysis of the mind. Had he lived, hardly too much could have been expected" (Upham 1827, p. 200).

Marsh wondered how American philosophy, particularly the Unitarians, could embrace Thomas Brown so heartily, and Marsh pushed the issue in his "Preliminary Essay." According to Marsh, Brown maintained that "the same law of cause and effect is the law of the universe" and that these laws applied equally to "the moral ... no less than to the properly natural powers and agencies of our being" (Marsh 1829 , p. xxx). Thus, Marsh concluded that Brown's system still maintained that "[t]he acts of the free-will are pre-determined by a cause out of the will, according to the same law of cause and effect... The notion of a power in the will to act freely, is therefore nothing more than an inherent capacity of being acted upon, agreeably to its nature, and according to a fixed law, by motives which are present in the understanding" (Marsh 1829). Writing to Coleridge, Marsh emphasized his gambit, "the Unitarians, while they reject [Jonathan] Edwards and treat him with severity for his Calvinism ... give currency to Brown for views that would seem to lead to what is most objectionable in [Edwards's] work on the Freedom of the Will" (Duffy 1973, p. 80). ${ }^{21}$ For Marsh, either the Unitarians were closet determinists or they were glibly unaware of the problem.

But was this characterization fair? Apparently referencing Hedge and Upham, Marsh declared: "I feel authorized to take this statement partly from Brown's philosophy, because that work has been decidedly approved by our highest theological authorities" (Marsh 1829, p. xxx). Hedge's earlier Elements of Logick gave no hint about how human free will might function, and Hedge's edition of Philosophy of the Human Mind gave no further illumination. As for Thomas Brown, in the crucial section on "Power, Cause, and Effect," Brown argued that no agencies or "powers" existed distinct from their substance; substances were bound by the law of cause and effect; and Brown argued that people ascribed "power" to substances outside of the chain of causation because their senses could not perceive the full complexity of the chain of cause and effect (Brown 1827, pp. 42-46). Humans were clearly substances in Brown's system, and the only concession Brown gave to a will outside the chain of causation was God's. Brown gave no thorough account of how human will might be free of the law of cause and effect. In his final edition of Inquiry into the Relation of Cause and Effect (Brown 1835), Brown avoided the words "free," "liberty," and "power"; he criticized Thomas Reid's claim that one could will against one's desires; and he seemed to sink all notions of human agency into internal desires

20 Dixon has suggested that Brown's account of causation was similar to Hume's skepticism about the matter, but as will become clear in the following discussion, Brown seemed more inclined toward determinism than skepticism on the question. 21 JM to STC, 23 March 1829. 
without explaining where these desires came from and how in the end they differed from mechanical causation (Brown 1835, pp. 38-39, 45-48, 52-55, 59-62, 74-76, 361-62).

Marsh had found a chink in the Unitarian philosophical armor. As Daniel Walker Howe has observed, "The student who seeks for a comprehensive Harvard Unitarian refutation of Edwards ... is disappointed. In fact, antebellum Harvard moralists devoted remarkably little energy to the issue of free will, either as a logical or a psychological problem.... So they were content to accept the freedom of the will ... as a principle of common sense, and declare that it required no proof" (Howe 1970, pp. 67-68). Marsh wondered why a movement that constantly invoked "reason" against the orthodox Calvinists could not only fail to develop a nuanced response to Brown's determinism when adopting Brown's epistemology, but also fail to even read Kant's and Coleridge's different responses to the problem. The emigrant professor of German literature at Harvard, Charles Follen, patiently explained to Marsh that it would take some doing to supplant "the genteel and palatable philosophy of Brown" (Duffy 1973, p. 126). ${ }^{22}$

\section{Reason versus Understanding}

Like Common Sense, the scheme Marsh proposed believed in the intuitive truth of free will and causation, but by relying on the Kantian terminology of reason versus understanding and making them different functions of the mind, Marsh hoped to redraw the lines of intellectual discourse and push the Unitarians to reconsider their own definition of reason. For Marsh, the intuitive principles of the understanding differed only in degree from the way that animals perceived and interacted with the world, whereas those arising from reason differed in kind (Marsh 1829, pp. xxxix-xliii). The understanding could "abstract and generalize, and fore-cast events, and the consequences of our actions, and compare motives," and among other things it allowed human beings to intuit the law of cause and effect to get along in the physical world (Marsh 1829, pp. xxxiii, xl). On the other hand, reason distinguished human beings from brutes by revealing necessary mathematical truths, the moral law of conscience, self-consciousness, and the ideas of the soul, free will, immortality, God, and a spiritual realm fundamentally different from the physical world (Marsh 1829, p. xlii). (In the structure of the argument, the latter three came only after deep reflection on the first five.)

Marsh's reason-versus-understanding distinction certainly differed from the numerous first principles and categories of first principles posited by Scottish Common Sense, but Marsh seemed uninterested in providing a point-by-point polemic against Reid and Stewart and their list of intuitive principles. By refusing to be drawn in to such a polemic and by focusing instead on his primary targets-Locke, Brown, the Unitarians, free will, and the reason-versus-understanding distinction-Marsh allowed his readers to graft whatever Common Sense principles his readers wished into his new epistemology. As Marsh's "Preliminary Essay" was not a comprehensive philosophical treatise, he seemed more concerned with reinventing the intellectual discourse about reason to ward off Unitarian assaults and pave the way for a more thorough and more "spiritual" philosophy that could still in some sense be called "rational." He took his friend Ebenezer Tracy's advice, which Marsh quoted in the "Preliminary Essay" itself: "If you can once get the attention of thinking men fixed on this distinction between the reason and the understanding you will have done enough to reward the labor of a life" (Duffy 1973, p. 97). ${ }^{23}$ But the key to establishing this distinction was still the free will problem. Like Kant, and unlike Reid, Marsh wanted to make free will not just $a$ first principle of the mind, but a higher first principle of seminal intellectual, spiritual, and emotional importance.

Marsh seized upon the free will problem as his primary argument for publishing Aids. "Turn the matter as we will," insisted Marsh, "so long as we refuse to admit the existence in the will of a power capable of rising above this law [of cause and effect], and controlling its operation by

22 Charles Follen to JM, 14 April 1832.

23 Ebenezer C. Tracy to JM, 28 October 1829. 
an act of absolute self-determination, so long we shall be involved in perplexities both in morals and religion" (Marsh 1829, p. xxxiii). Marsh thought that establishing self-determination required a new way of speaking about the mind, and Marsh saw in Coleridge's system a way for addressing the issue. "The key to [Coleridge's] system will be found in the distinctions, which he makes and illustrates between nature and free-will, and between the understanding and reason" (Marsh 1829, p. xv). As we have seen, Reid had already made the distinction between nature and free will, but Marsh sought to exploit the distinction to explain how certain religious doctrines might be rational and yet unexplainable. "Admitting the power to originate an act or state of mind may be beyond the capacity of our understandings to comprehend," Marsh declared, "it is still not contradictory to reason; and that I find it more easy to believe the existence of that, which is simply incomprehensible to my understanding, than of that which involves an absurdity for my reason" (Marsh 1829, p. xxxiii). As Marsh saw it, beliefs could be incomprehensible and still not be absurd. One might even be unable to articulate a belief in the categories of the understanding, but it still might be rational to hold such a belief.

\section{Marsh, Kant, and Practical Reason}

Like Kant, Marsh's moral philosophy and definitions of reason passed through the free will problem. It is quite possible that Marsh obtained his insight into free will directly from Kant. He had begun reading Kant as early as 1821; until at least 1823 he possessed a volume of "Kant's Philosophy"; he was fluent in German and translated German texts in the 1820s; and most tellingly he requested all four volumes of Kant's Vermischte Schriften (1799) four months prior to publishing the "Preliminary Essay" (Torrey 1843, pp. 37, 43; Marsh 1823; Duffy 1973, p. 93). ${ }^{24}$ While there is no direct record of Marsh reading Kant's Groundwork for the Metaphysic of Morals (1785) or Kant's Critique of Practical Reason (1788), it seems likely that Marsh knew these much more important texts if he sought insight in Kant's miscellaneous essays just prior to publishing the "Preliminary Essay." These Kantian texts in moral philosophy were more well known, they had been in print longer, and they spoke directly to Marsh's argument. What is clear is that like Kant, Marsh used the free will problem as the lynchpin in his argument.

Kant distinguished not only between reason and understanding, but also between two types of reason, speculative reason and practical reason (Kant 1996a, p. 211). ${ }^{25}$ Speculative reason was involved in the construction of more elaborate ideas and theories than those furnished by the understanding's twelve categories (including concepts such as causation, substance, unity, plurality, etc.). When functioning properly, speculative reason organized the categories of the understanding when constructing scientific theories, but it did not directly receive sense data, therefore speculative reason required a return to sensuous impressions for empirical verification (Wartenberg 1992). ${ }^{26}$ The understanding and the speculative reason, functioning together, were what philosophers generally call 'reason' - the ability to organize, interpret, and construct arguments based upon evidence. But Kant went further, provoked by Hume and the problems of causation and free will. Kant, like the Common Sense philosophers, insisted that science could trust its fundamental reliance on the law of cause and effect because this law was an embedded category of the understanding, of the mind itself.

24 JM to George Ticknor, 26 July 1829. In March of 1829, Marsh wrote Coleridge to confess his indebtedness to Coleridge in helping him to understand Kant (JM to STC, 23 March 1829 in Duffy 1973, p. 80). But Marsh did not elaborate on the exact nature of the intellectual debt and Marsh's genuflection to Coleridge is difficult to interpret. As an unknown American, he was writing to the great poet for the first time, and the tone of the letter is ingratiating. While scholars often take the letter as evidence that Marsh knew nothing of Kant beyond what Coleridge taught him, Marsh's intent to consult Kant's miscellaneous essays prior to publishing Aids and after the letter to Coleridge suggests more knowledge of Kant than Marsh let on.

25 As will become clear, it is important to note that both are the same cognitive faculty of "pure reason": "Now, practical reason has as its basis the same cognitive faculty as does speculative reason so far as both are pure reason" (Kant 1996a, p. 211).

26 See especially pp. 228-33. 
The mind imposed order on sense impressions derived from the natural world, and causation was one of its most important and thoroughly reliable categories. However, Kant also maintained that since causation existed in the mind itself, the mind never had full access to things in themselves (or as he termed it the noumenal world) but only to its organized perceptions (phenomena) of the world.

In the Groundwork of the Metaphysics of Morals (1785) and the Critique of Practical Reason (1788), Kant used his complicated epistemology from the Critique of Pure Reason $(1781,1788)$ to explain how reason accounted for the seeming contradiction between natural causation and human free will (Kant 1996a, p. 218). Kant agreed with the vast majority of philosophers that reason and conscience provided a reliable guide to ethical action, but he criticized other moral philosophers who "maintain[ed] the mechanism of the will in deeds, but its freedom in words" (Kant 1996a, p. 219). He insisted that reason, when applied to morality (practical reason), unyieldingly mandated freedom of the will-this conclusion was as sure as any other conclusion that reason could form. But how could free will be reconciled with the seeming ironclad law of cause and effect? Kant had already argued that causation, and indeed time and space itself, were categories imposed on reality by the understanding and were not necessarily properties of objects and relations in the noumenal world (things in themselves). ${ }^{27}$ Thus, time, space, and causation could be compatible with free will functioning in the noumenal world, while phenomenal perception and the understanding's ability to articulate this compatibility would always be undermined by the constraints of time, space, and causation.

Again, there were great affinities with Reid and Stewart, who essentially maintained that causation was a first principle that applied to the external world while free will was a first principle that applied to the mind (Reid 1813, p. 415-20; Reid 1815a, p. 170-72, 194-208; Reid 1815b, p. 284; Stewart 1829, pp. 574-75). But as previously mentioned, Reid also seemed to suggest that the idea of causation itself was actually derived from our more fundamental belief in free will, and he ultimately claimed that "when I attempt to comprehend the manner in which an efficient cause operates, either upon body or upon mind, there is a darkness which my faculties are not able to penetrate" (Reid 1815a, pp. 381-90, 402). Kant thought his system gave a more thorough explanation of the darkness Reid experienced. For Kant, the mind was both part of the phenomenal and the noumenal world; a person "must represent and think of himself in this twofold way" (Kant 1996b, p. 103). ${ }^{28}$ Kant insisted that the "pure reason independent of sensibility, gives the [moral] law," which necessarily entailed free will, and that in this realization one "is his proper self" whereas in all other, non-moral matters "he is only the appearance of himself" or a phenomenon (Kant 1996b, p. 104). On Kant's view, Reid experienced darkness in explaining free will because the categories of the understanding, which could only yield knowledge when combined with sense data, were attempting to explain a higher principle of moral reason and the noumenal self. The key difference between Kant and Reid was that Kant's system privileged morality and therefore free will at all costs, rendering free will a first principle above those that regulated conception of the material world. It was the emphasis on free will as a higher principle that attracted Marsh to Coleridge, who attempted to use it to establish the rationality of spiritual language and certain seemingly irrational Christian doctrines.

Understanding the free will problem and Kant's moral philosophy in detail is important to interpreting how Marsh could possibly think that reason could discover moral truths that lay beyond the understanding's ability to express those truths. To date Marsh commentators have eschewed a careful comparison of Marsh to Kant's moral philosophy, and most Marsh scholars have relied on Henry Pochmann on Kantian questions (Duffy 1970b, p. 194; Duffy 1973, pp. 25-26; Harding 1979,

27 Technically time and space were a kind of manifold through which sense impressions came to the mind, while the categories of the understanding used time and space to apply themselves to sense impressions. The result for Kant's argument and our purposes is the same.

28 Exemplifying the general trend when interpreting Marsh, Anthony Harding identifies the second part of this binary, citing Kant's Critique of Pure Reason, but Harding does not point to the first part of the binary, which is central to Kant's moral philosophy, see (Harding 1979, p. 240). 
p. 239; Carafiol 1982, p. 198; Beer 1993, pp. cxix-cxx). Pochmann accused Marsh and Coleridge of an un-Kantian leap to practical reason, but without citing any of Kant's texts on moral philosophy. Thus Pochmann made "pure reason" the antithesis of "practical reason" in his analysis (Pochmann 1957, pp. 136-37). ${ }^{29}$ But Kant not only speaks of "practical reason" as "pure" in the Critique of Practical Reason, the practical reason enjoyed "primacy" for Kant, as the great Kant scholar, Lewis White Beck, has shown (Beck 1960, p. 263). For Kant, according to Beck, "we have not two reasons, but one reason with two interests" (the speculative and the moral) (Beck 1960)..$^{30}$

\section{Free Will and Romantic Consciousness}

For several iconic thinkers, the problem of determinism helped animate what scholars, for better or worse, have identified as Romanticism. Kant's explanation of the free will problem came at a steep price, namely the inaccessibility of the noumenal world and a psychologically divided self. But Kant dared his opponents to give a more consistent account. "I do not see how those who insist on regarding time and space as determinations belonging to the existence of things in themselves would avoid fatalism of actions" (Kant 1996a, p. 221). ${ }^{31}$ Kant's psychological terror at the idea of determinism and his obsession with the free will problem has led Isaiah Berlin to aptly label Kant a "restrained romantic." Kant was restrained in his rationalistic contempt for vagueness, mysticism, or enthusiasm, but Romantic in his obsessive need to liberate free will at all costs and so liberate the moral self (Berlin 1999, pp. 69-75). Such a terror at determinism likewise animated William Wordsworth as he constructed in "Tintern Abbey" (1798) what Brian Barbour has called his "new worldview [of] Romanticism" (Barbour 1993, p. 151). ${ }^{32}$ While Stewart and Reid ultimately threw up their hands and appealed to God as the ground of free will, Kant's obsession led him to take one more step and jettison the mind's access to the noumenal world in order to give free will a fully separate realm in which to operate (Reid 1815a, p. 406; Stewart 1829, p. 577). Indeed, one might say that in a positive sense Kant's moral theory-with its emphasis on self-consciousness and self-determination-inspired the German Romantics, while Kant's metaphysical dualism haunted and agitated their creative attempts to reconnect the self with nature where they never quite shook the spectre of determinism (Beiser 2003, pp. 149-54, 170). For many poets and philosophers in England, Germany, and the United States, the apotheosis of the human mind itself-its self-consciousness, its endless creative potential, its excelsior moral law, and its godlike perception—-became the only place where Kant's haunting dualism could be transcended.

Marsh shared Kant's simultaneously intellectual and emotional Romantic obsession with the question of the human will. Part of the reason that Marsh blanched at the American receptivity to Thomas Brown was that Brown had prompted much of Marsh's skepticism and flight to Kant and Romantic sources in the first place. During his early studies, Marsh worried, "I find myself too strongly inclined to admit [Brown's] theory, independently of the reasoning by which it is supported, from the simplicity which it introduces into all our speculations on the phenomena and powers of nature" (Torrey 1843, p. 42). But the problem was also deeply emotional. Writing to his pious fiancée in the same year that he began to delve into Coleridge, Kant, and Madame de Staël, Marsh declared:

29 For a clear divide between "pure reason" and "practical reason" see also (Wells 1943, p. 26).

30 See also Kant: "Thus, in the union of pure speculative with pure practical reason in one cognition, the latter has primacy ... without this subordination a conflict of reason with itself would arise ... one cannot require pure practical reason to be subordinate to speculative reason and so reverse the order since all interest is ultimately practical and even that of speculative reason is only conditional and is complete in practical use alone" (Kant 1996a, p. 237-38 and fn. 64).

31 Kant's critique about space and time was perceptive, for Reid could be found to suggest that they were both imposed on matter by the mind and that they were simply part of matter itself. Stewart, sensitive to Kant's critique, attempted to answer the question by saying that space and time were neither part of the mind nor of matter, but rather special metaphysical entities he called "mathematical affections," which Jonathan Friday has concluded were underdeveloped in Stewart's account and "hardly less problematic than anything in Kant's metaphysics," see (Friday 2005, pp. 284-86).

32 On Wordsworth's crisis of determinism in his dejection following the French Revolution, recounted in The Prelude, XI:275-333, see also (Beer 1993, p. cxviii). 
The simple, unlearned Christian ... knows nothing of the ten thousand distracting questions, the harrowing doubts and maddening skepticisms, that dry up the heart and seethe in the brain of the unfortunate student, who has ventured to pass the consecrated limit of his traditional faith. ... [This] daring and ill-starred adventurer ... must not only unravel the mysteries of "[sic] fate, free-will, foreknowledge absolute, \&c., without getting lost in their mazes, but while floundering in an everlasting 'hubbub wild' of ancient learning crazed, and made to dance, like Epicurus' atoms, to the 'harmonious discord' of some German metaphysical bagpipe, he must be careful to keep his balances nicely adjusted. ... (Torrey 1843, pp. 45-47). ${ }^{33}$

Marsh's fears about "fate, free-will, [and] foreknowledge"—enhanced by the allusion to Epicurean materialism - are clear enough. But his intellectual angst became poignantly clear in his invoking Milton's "everlasting 'hubbub wild'" where Chaos, Tumult, Confusion, and Discord reigned in the Abyss between Heaven, Hell, and Earth-a place where Marsh seemed to have found himself as he suggested that his journey was "little less difficult than that of our great adversary, when he passed ... 'Wide on the wasteful deep'" (Torrey 1843, p. 46; Milton 2005, II. pp. 949-1006). Multiplying metaphors, he continued to compare his experience with Chateaubriand listening to the groans of Sodom and Gomorrah rising from the Dead Sea and to Dante arriving at paradise only after "first going through hell and purgatory" (Torrey 1843, p. 47). ${ }^{34}$ In addition to Marsh's Romantic concern with determinism and the liberation of the self, Marsh had clearly embraced a capacious Romantic consciousness and expressive idiom-invoking Dante, Milton, and Chateaubriand. ${ }^{35}$ He seemed to yearn for the liberation that Dante found after passing through Purgatory, where Virgil releases him declaring: "Free, upright and whole is thy free-will and it were a fault not to act on its bidding; therefore over thyself I crown and mitre thee." (Alighieri 1961, p. 357).

\section{Conclusions}

Marsh thought that distinguishing between reason and understanding provided a new idiom for expressing how free will simultaneously violated the mind's intuitive belief in causation but did not violate reason. For Marsh, it was not irrational to believe in mysteries if the moral reason warranted such mysteries. "A truth may be mysterious ..., , Marsh insisted, "But though we may believe what 'passeth all understanding,' we cannot believe what is absurd, or contradictory to reason" (Marsh 1829, p. xv). Free will existed, but when the understanding attempted to comprehend it, it became lost in mystery. Free will was mysterious, but this did not mean it contradicted reason, in fact reason revealed it. Reason might bring one to a belief that violated the understanding.

The route to free will lay through the moral realm, and Marsh's attraction to Coleridge went beyond the free will problem and the reason-versus-understanding distinction. In Aids, Coleridge hoped to persuade his audience that if moral reason could reveal truths such as free will and the moral law, then perhaps reason could render faith in morally relevant Christian doctrines rational—at least in some broad sense. If for example one concluded that reason revealed an unbending moral law-as Kant allowed—and if reason revealed humans' utter incapacity to fulfill that law-as history seemed to show-then perhaps assent to the Christian scheme of redemption—including the Trinity and the Incarnation-could somehow accord with reason. ${ }^{36}$ Marsh and Coleridge were incredibly coy on this point throughout the text. Was faith distinct from reason or not? But if the reason-versus-understanding

3 JM to Lucia Wheelock Marsh, 1 July 1821.

JM to Lucia Wheelock Marsh, 1 July 1821.

35 On the importance of Dante to the Romantic generation see (Eichner 1972, p. 12). On Milton see (Abrams 1971, pp. 21-29, 299-300). On de Staël as framing a new movement called "Romanticism" around such disparate writers as Wordsworth and Chateaubriand see (Isbell 1994, no page) cited in (Prickett 2010, pp. 15-16).

36 Such a position can be gleaned from aphorisms in Aids to Reflection, the theology of which is beyond the scope of this essay (Coleridge 1829, pp. 117-18, 120, 129). Douglas Hedley has identified the Trinity as the "hidden agenda" in Aids to Reflection (Hedley 2000, p. 8). Marsh apparently saw this as well for shortly after publishing Aids, he wrote to Coleridge eagerly 
distinction was the thesis of Marsh's preliminary essay, and if the free will problem was its driving force, Marsh also provided Coleridge's misty and chaotic Aids to Reflection with a thesis of its own. As an astute reader of Coleridge, Marsh drew from the Biographia Literaria (1817) to give his readers a working thesis for the Aids to Reflection: "The scheme of Christianity, though not discoverable by reason, is yet in accordance with it-that link follows link by necessary consequence-that religion passes out of the ken of reason only where the eye of reason has reached its own horizon-and that faith is then but its continuation" (Marsh 1829, p. xiv). In this Pascalian formula, the horizon of reason became a critical symbol for Marsh and Coleridge as they sought to draw heaven and earth together and restore the harmony between the mind, nature, and God that even Kant could not allow (Pascal 1995, p. 56).

Marsh's position on the free will problem clearly differed from Edwards, Brown, and any Americans inclined to admit their systems, and it injected the catalytic reason-versus-understanding distinction into American intellectual discourse. Marsh's approach to the problem not only employed Kantian terminology, it followed Kant's moral argument more closely than is often seen. But Marsh's position was also philosophically consistent with Reid's and Stewart's claim that both causation and free will were intuitive properties of the mind. In fact, the way Marsh drew his epistemological distinctions, he could accommodate a great deal of Reid's and Stewart's systems; Reid after all had labeled all the intellectual powers "the understanding" (Reid 1814, p. 65). But Marsh hoped that if he could get Americans to conceive in his new idiom-that beliefs might violate the understanding without becoming irrational or contrary to reason-then he might be able to blunt attacks on alleged irrational Christian doctrines. While Marsh's vindication of traditional Christian doctrines could not ultimately persuade Unitarians of the Trinity or Christ's divinity, the ideas that he and Coleridge outlined in the Aids to Reflection were not ephemeral. In addition to Marsh's influence on Emerson and the Transcendentalists, he introduced a new spiritual vitality into more orthodox forms of American religion, evidenced by the hundreds of copies disappearing off of booksellers' shelves at the orthodox Andover seminary and elsewhere.

Acknowledgments: The author wishes to thank the Boston University Humanities Foundation and the Robert V. Shotwell Dissertation Fellowship committee for valuable support in the initial stages of researching this essay. Great appreciation also goes out to the Thomas Jefferson Center at the University of Texas at Austin, the Jack Miller Center, and Belhaven University who provided valuable support while revising the argument. The author would also like to thank Charles Capper and Jon Roberts for insightful readings of early drafts of the essay; Jeffrey Marshall and the University of Vermont Special collections for their kindness and help; and Kenneth Sacks and the Religions editorial staff for the opportunity to present the essay in this collection.

Conflicts of Interest: The authors declare no conflict of interest.

\section{References}

Abrams, M. H. 1971. Natural Supernaturalism: Tradition and Revolution in Romantic Literature. New York: Norton. Adams, Robert Merrihew. 1998. Introduction. In Religion within the Boundaries of Mere Reason, 10th reprint. Cambridge Texts in the History of Philosophy. Translated and Edited by Allen Wood and George Di Giovanni. New York: Cambridge University Press, pp. vii-xxxii.

Alighieri, Dante. 1961. Purgatorio: The Divine Comedy. Translated by John D. Sinclair. New York: Oxford University Press.

Ameriks, Karl. 2005. A Commonsense Kant? Proceedings and Addresses of the American Philosophical Association 79: 19-45. [CrossRef]

Barbour, Brian. 1993. Between Two Worlds': The Structure of the Argument in 'Tintern Abbey. Nineteenth-Century Literature 48: 147-68. [CrossRef]

Beck, Lewis White. 1960. A Commentary on Kant's Critique of Practical Reason. Chicago: University of Chicago Press. 
Beer, John. 1993. James Marsh's Edition of 1829 and the American Reception. In Aids to Reflection. The Collected Works of Samuel Taylor Coleridge. Edited by John Beer. Princeton: Princeton University Press, vol. 9, pp. cxvi-cxxviii.

Beiser, Frederick C. 2003. The Romantic Imperative: The Concept of Early German Romanticism. Cambridge: Harvard University Press.

Berlin, Isaiah. 1999. The Roots of Romanticism. Edited by Henry Hardy. Princeton: Princeton University Press.

Breckman, Warren. 2008. European Romanticism: A Brief History with Documents. Boston: Bedford/St. Martins.

Brown, Thomas. 1827. A Treatise on the Philosophy of the Human Mind, 2 vols. Edited by Levi Hedge. Cambridge: Hilliard and Brown.

Brown, Thomas. 1835. Inquiry into the Relation of Cause and Effect, 4th ed. London: H. G. Bohn. First published 1818. Buckham, John Wright. 1904. James Marsh and Coleridge. Bibliotheca Sacra 61: 305-17.

Buell, Lawrence. 1973. Literary Transcendentalism: Style and Vision in the American Renaissance. Ithaca: Cornell University Press.

Capper, Charles. 2007. Margaret Fuller: An American Romantic Life, Volume II: The Public Years. New York: Oxford University Press.

Carafiol, Peter C. 1975. James Marsh: Transcendental Puritan. Emerson Society Quarterly 21: 127-36.

Carafiol, Peter C. 1982. Transcendent Reason: James Marsh and the Forms of Romantic Thought. Tallahassee: Florida State University Press.

Channing, William Ellery. 1843. Unitarian Christianity: Discourse at the Ordination of the Rev. Jared Sparks. In The Works of William E. Channing, 2nd ed. Boston: J. Munroe and Company, vol. 3, pp. 59-104.

Coleridge, Samuel Taylor. 1829. Aids to Reflection: With a Preliminary Essay, 1st American ed. Edited by James Marsh. Burlington: Chauncy Goodrich.

Conser, Walter H. 1986. James Marsh and the Germans. The New England Quarterly 59: 259-66. [CrossRef]

Conser, Walter H. 1993. God and the Natural World: Religion and Science in Antebellum America. Columbia: University of South Carolina Press.

Cranston, Maurice William. 1994. The Romantic Movement. Oxford: Blackwell.

Dewey, John. 1941. James Marsh and American Philosophy. Journal of the History of Ideas 2: 131-50. [CrossRef]

Dixon, Thomas. 2003. From Passions to Emotions: The Creation of a Secular Psychological Category. Cambridge: Cambridge University Press.

Duffy, John J. 1970a. From Hanover to Burlington: James Marsh's Search for Unity. Vermont History 38: 27-48.

Duffy, John J. 1970b. Problems in Publishing Coleridge: James Marsh's First American Edition of Aids to Reflection. The New England Quarterly 43: 193-208. [CrossRef]

Duffy, John J. 1973. Coleridge's American Disciples: The Selected Correspondence of James Marsh. Amherst: University of Massachusetts Press.

Eichner, Hans. 1972. Introduction. In "Romantic" and Its Cognates/The European History of a Word. Edited by Hans Eichner. Toronto: University of Toronto Press, pp. 3-16.

Emerson, Ralph Waldo. 1939. The Letters of Ralph Waldo Emerson. Edited by Ralph L. Rusk and Eleanor M. Tilton. New York: Columbia University Press.

Fairchild, Hoxie Neale. 1974. Romantic Religion. In Romanticism: Points of View, 2nd ed. Edited by Robert F. Gleckner and Gerald E. Enscoe. Detroit: Wayne State University Press, pp. 206-18.

Feuer, Lewis S. 1958. James Marsh and the Conservative Transcendentalist Philosophy: A Political Interpretation. The New England Quarterly 31: 3-31. [CrossRef]

Friday, Jonathan. 2005. Dugald Stewart on Reid, Kant and the Refutation of Idealism. British Journal for the History of Philosophy 13: 263-86. [CrossRef]

Frye, Northrop. 1974. The Drunken Boat: The Revolutionary Element in Romanticism. In Romanticism: Points of View, 2nd ed. Edited by Robert F. Gleckner and Gerald E. Enscoe. Detroit: Wayne State University Press, pp. 298-313.

Greenwood, Douglas McCreary. 1984. James Marsh. In The Transcendentalists: A Review of Research and Criticism. Edited by Joel Myerson. New York: Modern Language Association of America, pp. 343-47.

Gura, Philip F. 2007. American Transcendentalism: A History. New York: Hill and Wang.

Harding, Anthony John. 1979. James Marsh as Editor of Coleridge. In Reading Coleridge: Approaches and Applications. Edited by Walter Byron Crawford. Ithaca: Cornell University Press, pp. 223-51. 
Harvey, Samantha. 2011. Coleridge's American Revival: James Marsh, John Dewey, and the Legacy of Vermont Transcendentalism. Symbiosis: A Journal of Anglo-American Literary Relations 15: 77-103.

Harvey, Samantha. 2013. Transatlantic Transcendentalism: Coleridge, Emerson, and Nature. Edinburgh: Edinburgh University Press.

Hedley, Douglas. 2000. Coleridge, Philosophy, and Religion: Aids to Reflection and the Mirror of the Spirit. New York: Cambridge University Press.

Holifield, E. Brooks. 2003. Theology in America: Christian Thought from the Age of the Puritans to the Civil War. New Haven: Yale University Press.

Howe, Daniel Walker. 1970. The Unitarian Conscience: Harvard Moral Philosophy, 1805-1861. Cambridge: Harvard University Press.

Howe, Daniel Walker. 1997. Making the American Self: Jonathan Edwards to Abraham Lincoln. Cambridge: Harvard University Press.

Huntington, Charles Andrew. 1892. The University of Vermont Fifty Years Ago. Burlington: Whitney \& Stanley.

Isbell, John Claiborne. 1994. The Birth of European Romanticism: Truth and Propaganda in Stael's 'De l'Allemagne' 1810-1813. Cambridge: Cambridge University Press.

Kant, Immanuel. 1996a. Critique of Practical Reason. In Practical Philosophy. Translated and Edited by Mary J. Gregor. Cambridge Edition of the Works of Immanuel Kant. New York: Cambridge University Press, vol. 5, pp. 137-271.

Kant, Immanuel. 1996b. Groundwork for the Metaphysics of Morals. In Practical Philosophy. Cambridge Edition of the Works of Immanuel Kant. Translated and Edited by Mary J. Gregor. New York: Cambridge University Press, vol. 5, pp. 37-108.

Kuklick, Bruce. 1985. Churchmen and Philosophers: From Jonathan Edwards to John Dewey. New Haven: Yale University Press.

Lindsay, Julian Ira. 1936. Coleridge and the University of Vermont. Vermont Alumni Weekly 15: 147-49, 154-55, 159-60, 171-72, 178-79.

Lindsay, Julian Ira. 1954. Tradition Looks Forward: The University of Vermont: A History, 1791-1904. Burlington: University of Vermont.

Malherbe, Michel. 2003. The Impact on Europe. In The Cambridge Companion to the Scottish Enlightenment. Edited by Alexander Broadie. Cambridge: Cambridge University Press, pp. 298-315.

Marsh, James. 1823. Letter to "My dear Parents". 31 January 1823, Box 1, Folder 5, James Marsh Collection, Special Collections, University of Vermont Library.

Marsh, James. 1829. Preliminary Essay. In Aids to Reflection: With a Preliminary Essay, 1st American ed. Burlington: Chauncy Goodrich.

McGiffert, Arthur C. 1969. James Marsh (1794-1842): Philosophical Theologian, Evangelical Liberal. Church History 38: 437-58. Available online: http:/ / www.jstor.org.belhaven.idm.oclc.org/stable/3163519 (accessed on 14 August 2017). [CrossRef]

Meyer, Donald H. 1972. The Instructed Conscience: The Shaping of the American National Ethic. Philadelphia: University of Pennsylvania Press.

Miller, Perry. 1978. The Transcendentalists. New York: MJF Books.

Milton, John. 2005. Paradise Lost. Edited by Gordon Teskey. New York: W. W. Norton \& Company.

Mortera, Emanuele Levi. 2012. Stewart, Kant, and the Reworking of Common Sense. History of European Ideas 38: 122-42. [CrossRef]

Myerson, Joel. 2000. Introduction. In Transcendentalism: A Reader. New York: Oxford University Press, pp. xxv-xxxvii.

Nicolson, Marjorie H. 1925. James Marsh and the Vermont Transcendentalists. The Philosophical Review 34: 28-50. [CrossRef]

Noll, Mark A. 2002. America's God: From Jonathan Edwards to Abraham Lincoln. New York: Oxford University Press.

O'Brien, Michael. 2004. Conjectures of Order: Intellectual Life and the American South, 1810-1860. 2 vols. Chapel Hill: University of North Carolina Press.

Pascal, Blaise. 1995. Pensees. Translated by A. J. Krailsheimer. New York: Penguin Books.

Perry, Lewis. 1984. Intellectual Life in America: A History. New York: F. Watts.

Pochmann, Henry A. 1957. German Culture in America: Philosophical and Literary Influences, 1600-1900. Madison: University of Wisconsin Press. 
Prickett, Stephen. 2010. General Introduction: Of Fragments, Monsters, and Translations. In European Romanticism: A Reader. Edited by Stephen Prickett and Simon Haines. London: Bloomsbury Academic, pp. 3-20.

Reid, Thomas. 1813. Aristotle's Logic and Inquiry into the Human Mind. 4 vols. The Works of Thomas Reid. Charlestown: Samuel Etheridge, Jun'r., vol. 1.

Reid, Thomas. 1814. Essays on the Intellectual Powers of Man I-IV. 4 vols. The Works of Thomas Reid. Charlestown: Samuel Etheridge, Jun'r., vol. 2.

Reid, Thomas. 1815a. Essays on the Intellectual Powers of Man V-VIII and Essays on the Active Powers of the Human Mind I. 4 vols. The Works of Thomas Reid; Charlestown: Samuel Etheridge, Jun'r., vol. 3.

Reid, Thomas. 1815b. Essays on the Active Powers of the Human Mind II-V. 4 vols; Works of Thomas Reid; Charlestown: Samuel Etheridge, Jun'r., vol. 4.

Richardson, Robert D. 1995. Emerson: The Mind on Fire. Berkeley: University of California Press.

Rosenfeld, Sophia. 2011. Common Sense: A Political History. Cambridge: Harvard University Press.

Snow, Louis Franklin. 1907. The College Curriculum in the United States. New York: Teachers College, Columbia University.

Stewart, Dugald. 1829. The Philosophy of the Active and Moral Powers of Man. The Works of Dugald Stewart; Cambridge: Hilliard and Brown, vol. 5.

Sweeney, Douglas. 2003. Nathaniel Taylor, New Haven Theology, and the Legacy of Jonathan Edwards. New York: Oxford University Press.

Swift, David E. 1972. Yankee in Virginia. James Marsh at Hampden-Sydney, 1823-1826. The Virginia Magazine of History and Biography 80: 312-32.

Taylor, Nathaniel William. 1842. Concio Ad Clerum: A Sermon Delivered in the Chapel of Yale College, September 10, 1828. New Haven: A.H. Maltby and H. Hallock, First published 1828.

Joseph Gendall Torrey, ed. 1843. The Remains of the Rev. James Marsh, D.D., Late President, and Professor of Moral and Intellectual Philosophy, in the University of Vermont: With a Memoir of His Life. Burlington: Chauncey Goodrich.

Turner, James. 1985. Without God, Without Creed: The Origins of Unbelief in America. Baltimore: Johns Hopkins University Press.

Upham, Thomas Cogswell. 1827. Elements of Intellectual Philosophy: Designed as a Textbook. Portland: W. Hyde.

Wartenberg, Thomas E. 1992. Reason and the Practice of Science. In The Cambridge Companion to Kant. Edited by Paul Guyer. Cambridge: Cambridge University Press, pp. 228-48.

Wells, Ronald Vale. 1943. Three Christian Transcendentalists: James Marsh, Caleb Sprague Henry, Frederic Henry Hedge. New York: Columbia University Press.

White, Ruth Williams. 1965. James Marsh, Educational Pioneer. Educational Forum 29: 217-24. [CrossRef]

(C) 2017 by the author. Licensee MDPI, Basel, Switzerland. This article is an open access article distributed under the terms and conditions of the Creative Commons Attribution (CC BY) license (http://creativecommons.org/licenses/by/4.0/). 